\title{
Nutritional Quality and Quantity of Available Forages Relative to Demand: A Case Study of the Goitered Gazelles of the Golestan National Park, Iran
}

Elham Bagheri ${ }^{1}$, Mansour Mesdaghi ${ }^{2}$, Norhayati Ahmad ${ }^{1}$, and Maimon Abdullah ${ }^{1}$

${ }^{1}$ Faculty of Science and Technology, School of Environmental Sciences, Biology Programme, National University of Malaysia, Bangi, Malaysia 43000

${ }^{2}$ Department of Environmental Science, University of Ferdowsi Mashad, Iran (Mesdaghi)

Corresponding Author: Elham Bagheri, Faculty of Science and Technology, School of Environmental Sciences, Biology Programme, National University of Malaysia, A.3A.3A, Juta Mines Condominium, Taman Permi 1, Seri Kembagan, 43300 Serdang, Se serdang, 43300 MALAYSIA, elham_bagherirad@yahoo.com, Phone: 0060122440468 


\title{
Nutritional Quality and Quantity of Available Forages Relative to Demand: A Case Study of the Goitered Gazelles of the Golestan National Park, Iran
}

\author{
By Elham Bagheri, Mansour Mesdaghi, Norhayati Ahmad, and Maimon Abdullah
}

Forage quality potentially influences the population dynamics of wild ungulates. A lack of specific nutrient requirements can restrict the distribution of ungulates ${ }^{1}$ and herd movements and habitat selection are influenced by seasonal variations in quantity and quality of ungulate diet ${ }^{2}$. Recent studies of some wild ungulates suggest that lack of adequate forage quality and quantity in habitats could reduce survival and pregnancy rates ${ }^{3,4}$, delay breeding and parturition, and reduce the growth of calves and yearlings ${ }^{5}$. Animal growth and development during the grazing season depends on the nutritional contents of available forage. Therefore, good information on forage quality will help range managers to strike a balance between the animals' requirements and available forage to achieve optimal survivorship ${ }^{6}$.

In wild ungulates, changes in physiological demands for body maintenance, bone growth, weight gain, pregnancy, and lactation, call for variable nutritional requirements. The nutritional content of forage also changes according to seasonal environmental fluctuations. Therefore, the need to comply with nutritional demands can motivate the ungulates to distribute and move about throughout the year when seeking forage. If the animals fail to get their minimum nutritional requirements, they will suffer weight loss, reduced fertility, decreased milk production, and lowered reproductive rates, as well as a weakened immune system, which results in a greater susceptibility to infectious diseases and parasites. Vital information on the ability or inability of forage to meet the essential requirements of these animals is crucial in determining the reasons for population decline or poor growth rates in the wild ${ }^{7}$.

Availability and quality of forage play an important role in the rate of food intake and the amount of nutrients and energy consumed by herbivorous mammals ${ }^{8}$. However, the reactions towards food deficiency differ among different species of ungulates, depending on several factors such as type of feeding (browsing or grazing), food availability, food preference, behaviour, etc. ${ }^{9}$. For example, during the dry seasons, browsing animals consume sufficient amounts of energy and nutrients in their food, while grazing animals suffer from food shortages, especially a deficiency of protein and energy content in their diet ${ }^{8,10}$. Food shortages in the dry seasons become a limiting factor in the population density of most ungulates; therefore, ensuring 
that the availability of adequate forage nutrients in the dry seasons is an important task for range managers. To obtain a quantitative estimate of food supply for wild herbivores, many parameters, such as availability and quality of forage, rate of food intake by the ungulates, forage digestibility, energy, and protein content of forage, etc., should be determined ${ }^{8}$.

\section{The Goitered Gazzelles of Golestan National Park}

The Golstan National Park (GNP) in Iran, covers an area of 91,859 hectares that has been conserved as a protected area since 1957. It is one of the most famous national parks in the Middle East because of its natural attributes that include a verdant and virgin forest, and a rich diversity of flora and fauna species. It is located to the east of the Caspian Sea, between $55^{\circ} 43^{\prime}$ to $56^{\circ} 17^{\prime} \mathrm{E}$ and $37^{\circ} 16^{\prime}$ to $37^{\circ} 31^{\prime} \mathrm{N}$. The goitered gazelle (Gazella subgutturosa subgutturosa) live in the steppe habitats of the GNP, scattered throughout the northern (Lohondor), South-eastern (Mirzabaylou plain) and eastern (Solegerd) parts of the region (Figure 1). These animals are vulnerable worldwide and have been experiencing a population decline in the GNP.

We conducted our study in a small part of the GNP called the Mirzabaylou plain, which is the main habitat of the goitered gazelle in the GNP, located between $56^{\circ} 07^{\prime}$ to $56^{\circ} 15^{\prime} \mathrm{E}$ and $37^{\circ} 18^{\prime}$ to $37^{\circ} 22^{\prime} \mathrm{N}$, covering an area of 3,565 ha. The elevation in our study area ranged from 1,100 to $1,300 \mathrm{~m}$ and the climate was characteristically arid to semi-arid. The annual average precipitation is $400 \mathrm{~mm}$, while the annual average temperature varies between $11.5^{\circ} \mathrm{C}$ to $17.5^{\circ} \mathrm{C}$, with an absolute minimum temperature of $-25^{\circ} \mathrm{C}$ and a reported maximum of $45^{\circ} \mathrm{C}$. The main coverage includes thick shrubs, evergreen, and annual vegetation, mostly belonging to IranTooranian elements. Artemisia spp., along with annual species and steppe communities provide good cover for the hills and valleys, giving an expanded shrub land landscape that is a suitable habitat for the wildlife species of the park, such as the gazelles, wild sheep, and goats. The vegetation composition of the study area, as measured by percentage canopy ground cover,

consisted of $58 \%$ shrub species, $25 \%$ grasses, and $17 \%$ forbs $^{11}$. The goitered gazelles coexist with a variety of important plant communities in the GNP (as described in Table 1).

Knowledge of diet quantity and quality, relative to demand in goitered gazelles, is essential in seeking the underlying reasons for their population decline in the wild, as well as for their conservation. Our current 
study has been designed to monitor changes in the available forage quality and quantity, in order to gain insights into forage characteristics, which could influence the gazelle's survivability. We measured biomass, crude protein, metabolisable energy, and mineral content in six species of shrubs, four species of grass, and two annual forb species, against the requirements of goitered gazelles in mid-spring, late spring, mid-summer, and late fall 2011.

The main objectives of our investigation are:

1) To determine the species composition and nutritional quality of forage consumed by the goitered gazelles in relation to their nutritional requirements, in the steppe area of the GNP;

2) To assess whether the forage nutritional quality and quantity meet the requirements of the goitered gazelles during the critical periods of their lives; and

3) To propose several management measures pertaining to the gazelle's habitat management.

\section{Available Forage Collection}

A correlation between accumulated faecal groups and canopy cover of vegetation species in the study area was used in an earlier study to determine the diet composition of the goitered gazelle during different seasons ${ }^{12}$. Species composition of consumed plants was also determined by visually observing foraging gazelles and checking which plants had been grazed. Six species of shrubs, four species of grasses, and two annual forb species were considered as the most commonly used forage by the goitered gazelles in our study area (Table 1).

The main shrubs included white wormwood (Artemisia herba-alba), Mediterranean saltwort (Salsola rigida), winterfat (Eurotia ceratoides), Russian thistle (Salsola vermiculata), and Anabasis aphylla. Dominant grasses consisted of silver feather grass (Stipa barbata), bulbous bluegrass (Poa bulbosa), bothperennial grasses, and the annual grass Eremopyrun bonaipartis. Over 10 forb species were present throughout the study area, in which the annual forbs, such as Alyssum strigosum and Asteragalus spp., were dominant and commonly used by the gazelles.

Food availability, and fluctuations in the quantity of the gazelle's diet, was monitored at different phenological stages. We determined species composition and the amount of forage 
biomass by harvesting the vegetation from 160 plots of $1 \times 1 \mathrm{~m}^{2}$ each, distributed evenly at $30 \mathrm{~m}$ intervals along twenty permanent transects of $210 \mathrm{~m}$ scattered throughout the study area. To estimate the biomass dynamics, we harvested forage plant samples along the transects several times during mid-spring, midsummer, end summer, and late fall in 2011. The green and edible plant parts in each sampling plot were clipped to ground level and stored in separate paper bags. After air drying, the clipped plant parts were oven dried at $70^{\circ} \mathrm{C}$ for $48 \mathrm{~h}$ to achieve a constant weight in the laboratory. The mean dry weight (to the nearest $0.01 \mathrm{~g}$ ) of each forage species was determined for the different seasons of 2011.

\section{Forage Collection and Preparation for Chemical Analysis}

For a quantitative estimation of food plant composition, we collected the edible and green parts of these plants in three phenological stages i.e., vegetative growth (first of May), flowering (first of August), and plant maturity stages (first of October). Individual plant species were collected from the study area's wild communities where they were most abundantly found and grazed by the gazelles. Three replicated fresh samples from the current year's growth were weighed at 50$100 \mathrm{~g}$ each. Each weighed replicated sample of three individual plants of each species was cut and properly stored in sealed paper bags. The plant samples were prewashed in deionized water, air-dried in paper bags to prevent fungal growth, and then stored for further analysis. When required, the air-dried samples were oven dried at $60^{\circ} \mathrm{C}$ over 48 hours. For further chemical analysis, oven-dried samples were ground to $2 \mathrm{~mm}$ and stored in plastic bags at room temperature prior to analysis.

The Nitrogen $(\mathrm{N})$ content of forage species was measured using the micro Kjeldahl method $^{13}$. Next, crude protein was calculated based on the formula:

\section{$\%$ Crude protein $=\% N \times 6.2$}

Acid Detergent Fiber (ADF) was determined by a 'fibertec' system method, as described by Van Soest $^{14}$, and Dry Matter Digestibility (DMD) was estimated using the formula suggested by Oddy et al. ${ }^{15}$ :

$$
\% D M D=83.58-0.824 A D F \%+2.626 N \%
$$


Metabolisable Energy (ME) level in forage was also predicted using the equation recommended by $\mathrm{AOAC}^{13}$; where ME/DM is the Metabolisable Energy in mega joules (MJ) per $\mathrm{Kg}$ of feed DM":

$$
M E=0.17 D M D \%-2
$$

We used a high-temperature oxidation or dry ashing method to quantitatively determine the concentration of macro and micro minerals. Digest analytical concentrations were determined by inductively coupled plasma atomic emission spectrometry ${ }^{16}$.

\section{Gazelle Nutritional Requirements}

The energy requirement of gazelles is calculated as the sum of its requirements for maintenance, lactation, and various other activity categories. The daily energy requirement for maintenance is determined based on the body weight of the animal ${ }^{17}$ :

$$
\text { Energy requirement }=440 \mathrm{kj} \text { per } M^{0.75} \text { per day }
$$

where $\mathrm{M}$ is the body weight $(\mathrm{kg})$ of the gazelle. The energy expenditures for the various activities of the animal are calculated from the daily percentage of each activity category, The factors (in relation to the maintenance level) for each activity are: lactation 2.30, feeding 1.5, walking 2.5 , and resting/standing $1.15^{17}$. As precise information on the mineral requirements of wild ungulates is still lacking, we presumed that the gazelle requirements are comparable with those of domestic animals, such as sheep and goats ${ }^{18}$.

\section{Seasonal Quantity Trend of Available Forage Base on Growth Forms}

We found the total biomass of shrubs was significantly higher than that of grasses and forbs in our study area in 2011. In spring, the total biomass of shrubs reached $290 \mathrm{~kg} / \mathrm{ha}$, but during early summer, it had declined rapidly to only about $100 \mathrm{~kg} / \mathrm{ha}$, and continued to decline to $50 \mathrm{~kg} / \mathrm{ha}$ in late summer. However, after the rains in fall, the total biomass of shrubs abruptly rose to 75 $\mathrm{kg} / \mathrm{ha}$, but declined again until the end of the growing season in deep winter, when the total biomass of shrubs reached its lowest of approximately $50 \mathrm{~kg} / \mathrm{ha}$. It seems that shrub biomass declined due to weather conditions and drought at the end of year. The total biomass of other growth forms of grasses and forbs were even much lower than that of shrubs, although without 
significant fluctuations across the seasons. Annual forbs and grasses appeared only in spring and summer, while shrubs and perennial grasses were dominant throughout the year, and provided the most substantial portion of the gazelle's food at all times (Figure 2). These findings indicate that food availability of the habitat is significantly influenced by phenological stages and growth forms.

\section{Seasonal Crude Protein Content of Forage Species in Relation to Gazelle Demand}

Significant differences ${ }^{\mathrm{i}}$ were detected in the crude protein $(\mathrm{CP})$ concentrations among forage species, between seasons, and between the species-season interactions. White wormwood, winterfat, Mediterranean saltwort, Anabasis aphylla, and Aellenia spp. CP levels exceeded good levels in all seasons, while CP levels of Russian thistle, tapertip false wheatgrass (Eremopyron bonaepartis), and Alyssum strigosum were below the requirements for the goitered gazelles in all seasons (Table 2). The CP levels of grasses generally exceeded good requirements in mid spring, and then rapidly declined to below the gazelle's requirement levels in the remaining seasons to the extent that in bulbous bluegrass the $\mathrm{CP}$ reached below minimum levels for maintenance. By end spring, the $\mathrm{CP}$ in all herbaceous plants was below the requirements for the gazelles. The highest CP was detected in Anabasis aphylla in mid spring (28.65 $\pm 0.13 \%)$, and the lowest was detected in bulbous bluegrass at the end of spring $(5.77 \pm 0.61 \%)$ (Table 2$)$.

Based on various studies ${ }^{19,20}$, a minimum value of $7 \% \mathrm{CP}$ is necessary to meet the maintenance requirements of ruminant herbivores. Cook et al. ${ }^{4}$, reported that fawns required 13$16 \% \mathrm{CP}$ for optimum growth, and Verme and Ullrey ${ }^{21}$ recommended feeding $13-20 \% \mathrm{CP}$; since $16-17 \%$ would meet the maximum requirements of most ungulates, including the lactating does.

During our study, the seasonal dietary levels of total forage never dropped below the maintenance needs level (Table 2). However, the optimum level of CP was only obtained in early spring. The availability of green browse, grasses, and forbs throughout the spring provided forage of high CP content, which is especially important in terms of fawn survival. As reported by Murphy and Coates ${ }^{19}$, fawn mortality increased among those does whose diet contained less than $14 \% \mathrm{CP}$, which was attributed to by neonatal loss due to delayed milk production.

${ }^{\mathrm{i}}(\mathrm{P}<0.05)$ 
The lack of green forage reduced the optimum CP levels throughout fall - a critical period in terms of mating. This was especially important for adult gazelles that tend to fast during rut. Since a foraging gazelle is more selective in its $\operatorname{diet}^{9}$, our results may represent a minimum estimate of the actual CP intake i.e., the animals might have had adequate protein. However, even with deficiency in the optimal level of CP during fall, the adequate level for gazelle maintenance is sufficiently met by all forage species in their habitat.

\section{Seasonal Metabolizable Energy Content of the Forage Species in Relation to the Gazelle Requirements}

Significant differences $^{\mathrm{ii}}$ in metabolizable energy (ME) concentrations was detected among forage species across seasons, and the species-season interactions. During our study, the ME levels in all forage species exceeded the maintenance demand for gazelles (see Table 4). Throughout the lactation season (in spring), white wormwood, winterfat, silver feather grass, bulbous bluegrass, tapertip false wheatgrass and Alyssum strigosum had ME levels below lactation requirements, while Mediterranean saltwort, Russian thistle, Anabasis aphylla, and Aellenia species were the shrub forages with ME contents that exceeded the lactation needs. Optimum levels of ME were obtained by consuming these shrub species, which also met the different annual energy requirement levels of the gazelles. The highest ME was detected in Anabasis aphylla in mid spring $\left(11.87 \pm 0.27 \mathrm{Mj} / \mathrm{kg}^{-1} \mathrm{DM}\right)$, and the lowest was detected in Alyssum strigosum in midsummer $\left(5.50 \pm 0.27 \mathrm{Mj} / \mathrm{kg}^{-1} \mathrm{DM}\right)$.

The results indicate that there were no significant differences in energy requirements between gazelles during different physiological statuses (i.e., maintenance, lactation, and mating), and activities (i.e., feeding, walking, and resting/standing). However, significant differences were observed between the activities and physiological statuses of male and female gazelles (see Table 3). Energy expenditure during walking was considerably more than for other activities, and lactating female gazelles needed more energy than males and non-lactating females.

ii $(\mathrm{P}<0.001)$ 
During our study, the seasonal ME levels of forage species never dropped below maintenance requirements of the gazelles (Table 4). However, energy expenditure by female gazelles during lactation slightly exceeded their intake and the high nutritional demands of animals during this period could present a problem to their well-being. Energy requirements during the mating period of gazelles were fully met by the metabolisable energy of available forages consumed. Among all activities, walking expended the most energy that could not be met by the seasonal energy levels in the forage consumed. We suppose that gazelles should be selective in seeking forage plants with high levels of energy to meet their requirements during lactation, especially when they are walking about, seeking to fulfil their food requirements, in times of food deficiency.

\section{Seasonal Macro- and Micro Mineral Content of Forage Species in Relation to the Gazelle Demands}

Generally, the average concentrations of mineral elements were significantly higher in fall than in spring. In comparing between species and seasons, the concentrations of macro- and micro elements in shrub species were markedly higher in fall; while for grass species, they were higher in spring (Tables 5 and 6).

The approximate average contents of most macro- and micro elements in the forage species of our study area were lower than the gazelles' requirements. With the exception of sodium $(\mathrm{Na})$, iron $(\mathrm{Fe})$, and manganese $(\mathrm{Mn})$, most of the mineral elements required during calving and lactating seasons, and necessary for bone growth and milk production, were either below the necessary concentrations or they exceeded tolerable levels. Throughout fall, the concentrations of macro minerals; especially for most shrub species, generally satisfied the requirements of the gazelles during the rutting period; however, they still suffered from a micro mineral deficiency in their diets. White wormwood was the only shrub species to provide sufficient macro- and micro minerals needed during fall i.e., when the gazelles start their mating behaviour (Tables 5 and 6).

During the year, the highest levels of macro minerals, i.e., $\mathrm{Na}, \mathrm{Ca}$, and magnesium $(\mathrm{Mg})$ concentrations, were found in the shrubs that exceeded the gazelles' requirements. Meanwhile, the highest concentrations of potassium $(\mathrm{K})$ were in the grasses that were below the gazelles' 
requirements (Table 5). High micro mineral concentrations were measured in grasses in the spring. , and shrubs in the fall, but which were unable to meet the gazelles' requirements (Table 6). Generally, shrub species abundant in the study area were more likely to meet the minimum mineral requirements of goitered gazelles.

\section{DISCUSSION}

Spring supports the greatest diversity of food categories in the GNP study area, and the gazelles ate most of the plants that they encountered during this season ${ }^{22}$. The preference for herbaceous species in spring ${ }^{12,22}$ was probably due to the high quantity and quality of grasses and forbs available in their early growth stages. The protein content of silver feather grass and bulbous bluegrass, the two main perennial grasses, exceeded the gazelles' requirements during calving and feeding after birth (at least 14\%). Succulent ephemerals were favoured by the gazelles due to their rich nutrients, vitamins, and water content ${ }^{23}$. Spring was an important season for the gazelles, during which time moulting, birthing, and rearing of their young occurred ${ }^{24}$. For these reasons, the gazelles consumed a wider range of plant species to meet their energy and nutritional requirements in spring. Although the content of protein, metabolisable energy, and mineral concentration of Eremopyron bonaris, Alyssum strigosum, and other annual forbs were unable to satisfy the food requirements of the gazelles in spring, they were likely to be consumed by the gazelles due to their high palatability, high soluble cell content ${ }^{14}$, and high digestibility. These ephemeral plants appeared in the study area most in spring, when their quality and quantity were at their best. Rapidly decreasing in summer, they were completely absent from the habitat during autumn and winter. We hypothosize that herbaceous species usually provide adequate nutritional forage for calving growth and good performance of the gazelles during their early growth stages. As spring progressed, the protein levels in grasses decreased more rapidly than in shrubs and forbs to eventually reach below the gazelle's minimum requirements. In other studies, by Cook $^{25}$, Van Soest ${ }^{14}$, and Beck and Peek ${ }^{10}$, the same trend in the nutritional quality of forages and demands in ungulates was reported.

Summer was the driest season in the study area. July and August were the warmest months (with a maximum temperature of $45^{\circ} \mathrm{C}$ ). Water deficiency can be a critical and determining factor in the survivability of the gazelles ${ }^{22,26}$. During water stress, the gazelles probably focused more on feeding on succulent plants, such as shrubs, as reliable water sources 
with more than $50 \%$ water, than grasses and forbs. In another study, we found positive correlations between the pellet group density of the gazelles and canopy cover of Aellenia spp during summer ${ }^{12}$. Besides high water content, some shrub species, such as Aellenia spp were also dominant forage, with protein and energy levels that exceeded good requirements for the goitered gazelle during the hot summer. It seems that the green bushes of Aellenia spp., along with other succulent shrubs species, could provide a sufficient food source for the gazelles during summer. Our findings confirmed the use of succulent species by the goitered gazelle, as noted by $\mathrm{Wei}^{22}$, who believed that due to a shortage of water in arid areas of China, the goitered gazelles had switched to a diet dominated by forbs with a high water content, such as Allium polyrhizum and Zygophyllum rosovii.

In the GNP, the cold period began in October and continued through to April. Also, fluctuations of monthly temperatures show that January and February were the coldest months, with a minimum temperature of $-26^{\circ}$ Cand approximately 22 frozen days ${ }^{27}$. The extreme cold weather associated with reduction in quantity and quality of forage likely increased the risk of gazelle mortality and forced them to flee into the surrounding farmlands to find food, which ultimately leads to hunting by villagers. Food shortages during harsh winters, due to cold temperatures and strong winds in the gazelle's habitat, were also reported by Hongjun et al. ${ }^{28}$.

In autumn, as most ephemerals dehydrate, species diversity in the gazelle's habitat rapidly decreases. Herbaceous availability and quality declines with the cold season, while shrubs become the more dominant and nutritional food sources. During autumn, the gazelles need food that has relatively high crude protein content ${ }^{22}$, because they are starting their rutting behaviour. As spring passes, the protein levels of silver feather grass and bulbous bluegrass decreased significantly, reaching below good requirement levels of the gazelles, such that in bulbous bluegrass, the protein levels reach below minimum requirements for maintenance for the rest of the year. Moreover, the high fiber content of these two perennial grasses increases with maturity more than in shrubs. Instead of perennial grasses, shrubs mainly white wormwood, Medeterranean saltwort, winterfat, and Anabasis aphylla, become the more available forages across autumn and winter. These plants' high levels of crude protein, metabolizable energy, and mineral concentrations, significantly meet the requirements of the goitered gazelle during mating and harsh winter. In fact, the dominance and distribution pattern of forage frequently has a great 
deal to do with its preference rating ${ }^{29,30}$. During the cold seasons, finding enough forage to satisfy the basic requirements of the animals is difficult; therefore, during food stress periods and low available food quantity and quality, herbivores generally use any edible forage available in their habitat ${ }^{22,31}$. The energy expended searching for nutritional forages, especially during the harsh seasons, is probably more than the metabolisable energy intake of the consumed forage. Therefore, as reported by Abaturov et al. ${ }^{8}$, the gazelles and other ungulates spend more time feeding and resting than they do walking. The results of our study indicate that energy expenditure during walking was more than the energy content in the available forage.

We detected seasonal variations in the mineral-nutrient content of forage species in the gazelles' habitat in our study area. Even though the highest concentrations of mineral elements in herbaceous plants occurred in the spring, the levels were below minimum requirements, and could lead to mineral deficiency and grass tetany for grazing gazelles during calving and lactating. The same mineral contents trend of several tropical grasses was reported in other studies e.g., Gomide ${ }^{32}$ and Underwood ${ }^{33}$, who studied macro- and micro mineral concentrations of grasses at different stages of growth, and found that as the forage reached maturity, the nutritional content declined for most of the minerals. Compared to herbaceous species, we found the highest concentrations of mineral elements in shrubs occurred in fall, when the plants matured, and the mineral contents were sufficiently high to meet some macro mineral requirements for browsing gazelles during mating behaviour.The highest concentrations of mineral elements for elk forages were also reported at the end of growing season by Beck and Peek ${ }^{10}$ in Nevada.

We found the levels of $\mathrm{Mg}, \mathrm{Ca}$, and $\mathrm{K}$, required macro elements during calving season ${ }^{26}$, would be insufficient to meet the gazelles' nutritional demands through food selection of available forage. The $\mathrm{Mg}$ levels of most edible plants for gazelles are lower than the supplemental amount needed during calving, or they have exceeded the maximum tolerable levels during mating season. The most significant disruption caused by $\mathrm{Mg}$ deficiency is an acute metabolic disorder called hypomagnesemic tetany (commonly referred to as grass tetany in grazers). Grass tetany and grass staggers usually occur in grazing animals during the early stages of lactation $^{34}$, and is more widespread in older animals. O'Kelley and Fontenot ${ }^{35}$ reported that despite variations among species, the $\mathrm{Mg}$ requirements for lactating animals were more than 
twice that required during the gestation period. However, excessive amounts of $\mathrm{Mg}$ in diets have been associated with the formation of magnesium-containing calculi in the urethra of animals, causing obstructions and subsequent death from ruptured bladders ${ }^{34}$. Under practical conditions, the application of supplements for the major minerals is most critical for $\mathrm{Mg}$; especially in individual lactating animals grazing in the spring, when the $\mathrm{Mg}$ supply is frequently marginal ${ }^{34}$.

Although, in arid regions, calcium deficiency in forages is comparatively rare ${ }^{36}$, during spring in our study area, Ca deficiency was evident in most of the available forage. Inadequate Ca levels could cause rickets in ruminants, especially during the initial stages of growth. Young ruminants require a larger dietary percentage of $\mathrm{Ca}$ than older animals ${ }^{37}$.

The presence of $\mathrm{K}$ is essential for the activation of several enzyme systems, including those involved in protein synthesis and carbohydrate metabolism. Several factors may cause potassium deficiency in animals, such as inadequate $\mathrm{K}$ intake (as seen in our study area), high salt consumption, gastrointestinal losses, and stressful conditions ${ }^{38}$. The deficiency symptoms of $\mathrm{K}$ include anorexia, depressed growth, muscular weakness, irritability, paralysis, and tetany. Insufficient $\mathrm{K}$ in the herbivores' diet may force them to consume unpalatable or poisonous plants in an effort to satisfy their requirements ${ }^{36}$.

In our study, most of the micro minerals, except for Fe and $\mathrm{Mn}$, were found to be deficient in all forage species throughout the seasons (Tables 5 and 6). Although the micro minerals are required in very small amounts, compared to the macro elements, they are essential for both animal growth and reproduction ${ }^{39}$.

Most animals require 24 mineral elements for growth and development, health, and survivability $^{40,41}$, all of which may not be found in any single forage species. Therefore, a variety of plant forms and species, rather than any single plant type, is required by gazelles to meet their nutritional demands for many macro- and micro-minerals. The most salient findings of our study indicate that, with the exception of $\mathrm{Na}, \mathrm{Fe}$, and $\mathrm{Mn}$, most edible forage plants in the gazelles' habitat in the GNP have inadequate mineral content during critical periods of their survival (Tables 5 and 6).

The gazelle's GNP habitat has limited forage nutrient levels required for their survival, growth, and reproduction. Two shrub species, Anabasis aphylla and Aellenia spp., had the most protein 
and energy levels, which exceeded the gazelles' requirements across all seasons. Mineral contents were the limiting nutrients for shrub species in meeting the gazelles' requirements, specifically in fall. White wormwood was the only species that could satisfy the mineral needs of the gazelles during fall. The potential for maintaining a relatively high density of gazelle populations, given the forage quality levels to fulfil their requirements, declines as spring approaches early summer in the GNP.

Average mineral concentrations of available forages were below minimum requirements during calving and mating periods, while mineral deficiencies or high toxicity levels in some common gazelle diets may adversely affect the animals and induce them to consume unpalatable or poisonous species. Without supplemental foods, the gazelles might be unable to satisfy their mineral requirements during peak activities by relying only on the available forage, risking death due to insufficient supply and body weakness. The gazelles would then be forced to seek other suitable habitats that would satisfy their needs. Management programmes for goitered gazelles in the GNP should focus on improving habitat quality and protect the gazelles against diseases and weight loss due to insufficient forage quality. This could also prevent the gazelles from encroaching upon farmlands adjacent to the park, preventing them from being killed by the villagers.

\section{MANAGEMENT IMPLICATIONS}

Effective management, conservation, and improvement rely on efficient information of wildlife food habits and nutritional requirements. This information is necessary in managing the goitered gazelles of the GNP to determine the availability of forage for the gazelles, select plant species for re-vegetation, and discover the causes of the gazelle movement and population decline. Maintaining highly productive gazelle herds in the GNP protected area requires managers to maintain plant communities with a diversity of shrubs, forbs, and grasses, in order to provide for the nutritional

needs of the gazelles. These management programmes should be made based on identified key forage species to predict a potential sustainable population of animals within the protected habitat.

Shrub species; especially white wormwood, Mediterranean saltwort, winterfat, and Aellenia spp., are the most available forage species in the GNP, and previously have been considered as the gazelles' main diet. These species should be considered for re-vegetation programmes. Autecological information of these species and other types of gazelle diet are 
necessary for re-vegetation programmes. Reforestation programmes in th GNP should be adopted to revive vegetation and palatable species' growth. Also, artificial reseeding of palatable species for gazelle should be done around the GNP. During drought years in our study area, the gazelles should be fed supplementary forage to prevent vegetation degradation and ensure sustainability of the gazelle population. Based on the results of our current study, most of the macro- and micro-nutrient minerals are deficient in dominant and common forage species for the gazelle. Therefore, we strongly recommend the supplementation of these minerals, together with salt $(\mathrm{NaCl})$.

\section{ACKNOWLEDGEMENTS}

We would like to thank the Iranian Department of the Environment (DoE); particularly the Golestan Provincial Office of DoE, for providing the logistical and financial support for our field surveys.

\section{REFERENCES}

1. Murray, M.G. 1995. Specific Nutrient Requirements and Migration of Wildebeest. Serengeti II 231-256.

2. Wilmshurst, J.F., J.M. Fryxell, B.P. Farm, A. Sinclair, and C.P. Henschel. 1999. Spatial Distribution of Serengeti Wildebeest in Relation to Resources. Canadian Journal of Zoology 77(8): 1223-1232.

3. Baker, D., and N. Hobbs. 1982. Composition and Quality of Elk Summer Diets in Colorado. The Journal of Wildlife Management 694-703.

4. Cook, R.C., D.L. Murray, J.G. Cook, P. Zager, and S.L. Monfort. 2001. Nutritional Influences on Breeding Dynamics in Elk. Canadian Journal of Zoology 79(5): 845-853.

5. Cook, J.G., B.K. Johnson, R.C. Cook, R.A. Riggs, T. Delcurto, L.D. Bryant, and L.L. Irwin. 2004. Effects of Summer-Autumn Nutrition and Parturition Date on Reproduction and Survival of Elk. Wildlife Monographs 155(1): 1-61.

6. Arzani, H., Z. Ahmadi, H. Azarnivand, and M. Bihamta. 2011. Forage Quality of Three Life Forms of Rangeland Species in Semi Arid and Semi Humid Regions in Different Phenological Stages. Desert 15(2): 71-74. 
7. Alldredge, M.W., J.M. Peek, and W.A. Wall. 2002. Nutritional Quality of Forages Used by Elk in Northern Idaho. Journal of Range Management 253-259.

8. Abaturov, B.D., F. Kassaye, G.V. Kuznetsov, M.R.D. Magomedov, and D.A. Petelin. 1995. Nutritional Estimate of Populations of Some Wild Free-Ranging African Ungulates in Grassland (Nechisar National Park, Ethiopia) in Dry Season. Ecography 18(2): 164172.

9. Bell, R.H. 1971. A Grazing Ecosystem in the Serengeti. Scientific American 225(1): 8693.

10. Beck, J.L., and J.M. Peek. 2005. Great Basin Summer Range Forage Quality: Do Plants Nutrients Meet Elk Requirements? Western North American Naturalist 65(4): 516-527.

11. Bagherirad, E., M. Amirkhani, M. Mesdaghi, and N. Ahmad. 2012. A Comparative Study of the Effects of Gazelle and Livestock Grazing on the Plant Community Characteristics on the Steppe Habitat of Golestan National Park, Iran. International Researcher 1(1): 35-46.

12. Bagherirad, E., N. Ahmad, M. Amirkhani, M. Abdullah, M. Mesdaghi, and A. Kabudi. 2014. Seasonal Habitat Use of Persian Gazelles (Gazella Subgutturosa Subgutturosa) Based on Vegetation Parameters at Golestan National Park, Iran. Arid Range Land and Management 28: 464-484.

13. AOAC. 2000. Official methods of analysis of the association of the analytical chemists. 17 Ed. Inc. Virginia, USA.

14. Van Soest, P.J. 1994. Nutritional Ecology of the Ruminant. Cornell University Press.

15. Oddy, V., G. Robards, and S. Low. 1983. Prediction of in Vivo Dry Matter Digestibility from the Fibre and Nitrogen Content of a Feed. Feed Information and Animal Production. Commonwealth Agricultural Bureaux, Farnham Royal, UK 395-398.

16. Munter, R. and R. Grande. 1981. Plant Analysis and Soil Extract Analysis by Icp-Atomic Emission Spectrometry. Developments in Atomic Plasma Spectrochemical Analysis. Heyden and Son, Ltd., London, England 653-672.

17. Owen-Smith, N., and S.M. Cooper. 1989. Nutritional Ecology of a Browsing Ruminant, the Kudu (Tragelaphus Strepsiceros), through the Seasonal Cycle. Journal of Zoology 219(1): 29-43.

18. National Research Council. 2007. Nutrient Requirements of Small Ruminants: Sheep, Goats, Cervids, and New World Camelids. Washington, DC: National Academies Press. 
19. Murphy, D.A. and J. Coates. 1966. Effects of Dietary Protein on Deer. Transactions of the North American Wildlife and Natural Resources Conference, hlm. 129-139.

20. Wallmo, O., L. Carpenter, W. Regelin, R. Gill, and D. Baker. 1977. Evaluation of Deer Habitat on a Nutritional Basis. Journal of Range Management 122-127.

21. Verme, L. and D. Ullrey. 1972. Feeding and Nutrition of Deer. Digestive Physiology and Nutrition of Ruminants 3: 275-291.

22. Wei, L. 2012. Diet of Gazella Subgutturosa (Güldenstaedt, 1780) and Food Overlap with Domestic Sheep in Xinjiang, China. Folia Zool 61(1): 54-60.

23. Xia, Y. 1993. The Type of Plant Communities and the Main Herbing Plants at the South Edge of Gurbantongut Desert. Arid Zone Research 10(3): 21-27.

24. Zhevnerov, V. 1984. Goitered Gazelle of the Barsa-Kelmes Island. Alam-Ata Nauka Press of the Kazakh SSR.

25. Cook, C.W. 1972. Comparative Nutritive Values of Forbs, Grasses and Shrubs. Wildland shrubs-their biology and utilization. USDA Forest Service, General Technical Report INT-1, Ogden, UT 303-310.

26. Olson, K.A., M.G. Murray, and T.K. Fuller. 2010. Vegetation Composition and Nutritional Quality of Forage for Gazelles in Eastern Mongolia. Rangeland Ecology \& Management 63(5): 593-598.

27. Madjnoonian, H., B. Zehzad, B. Kiabi, B.F. Darrehshoori, and H.G. Meigouni. 1999. Golestan National Park: Biosphere Reserve, (in Persian), Department of the Environment of Iran. Tehran.

28. Hongjun, C., J. Zhigang, G. Yan, J. Feng, T. Yongshan, and W. Chen. 2009. Population Densities and Number of Khulan and Goitred Gazelle in Mt. Kalamaili Ungulate Nature Reserve. Biodiversity Science 17(4): 414-422.

29. Jarman, P. 1974. The Social Organisation of Antelope in Relation to Their Ecology. Behaviour 48: 215-267.

30. Martin, C. 1977. Status and Ecology of Barasingha (Cervus Duvauceli Branderi) in Kanha National Park (India). Journal of the Bombay Natural History Societv 47(1): 60132.

31. Belovsky, G.E. 1994. How Good Must Models and Data Be in Ecology? Oecologia 100: 475-480. 
32. Gomide, J. 1978. Mineral Composition of Grasses and Tropical Leguminous Forages. Latin American Symposium on Mineral Nutrition with Grazing Ruminants (Editors: J H Conrad and LR McDowell) University of Florida, Gainesville pp32-40, hlm.

33. Underwood, E.J. 1999. The Mineral Nutrition of Livestock [Electronic Resource]. Cabi.

34. Agricultural Research Council. 1980. The Nutrient Requirement of Ruminant Livestock. Gresham Press, Old Working, Surrey, U.K.

35. O'kelley, R. and J. Fontenot. 1969. Effects of Feeding Different Magnesium Levels to Drylot-Fed Lactating Beef Cows. Journal of animal science 29(6): 959-966.

36. Assaeed, A.M., M. Al-Saiady, and A. Al-Jaloud. 1995. Towards Formulating a Management Plan for Farasan Wildlife Reserve. A Report on results of field and laboratory research and observations. NWCD, Riyadh 40.

37. Ammerman, C. and R. Goodrich. 1983. Advances in Mineral Nutrition in Ruminants. Journal of Animal Science 57(2): 519-533.

38. Welt, L., W. Hollander Jr, and W. Blythe. 1960. The Consequences of Potassium Depletion. Journal of Chronic Diseases 11(3): 213-254.

39. Stare, F. and C. Elvehjem. 1933. Cobalt in Animal Nutrition. Journal of Biological Chemistry 99(2): 473-483.

40. Nieminen, M. and U. Heiskari. 2010. Diets of Freely Grazing and Captive Reindeer During Summer and Winter. Rangifer 9(1): 17-34.

41. Staaland, H. and R.G. White. 2001. Regional Variation in Mineral Contents of Plants and Its Significance for Migration by Arctic Reindeer and Caribou. Alces 37(2): 497-509.

Authors are Researcher, Faculty of Science and Technology, School of Environmental Sciences, Biology Programme, National University of Malaysia, Bangi, Malaysia 43000 (Bagheri, elham_bagherirad@yahoo.com); Professor, Department of Environmental Science, University of Ferdowsi Mashad, Iran (Mesdaghi); Assocaite Professor, National university of Malaysia, Bangi, Malaysia. 43000 (Ahmad); and Professor, National university of Malaysia, Bangi, Malaysia. 43000 (Abdullah). We would like to acknowledge the DPP-2013-067 Grant from Universiti Kebangsaan Malaysia (UKM) for partially funding this study. 


\section{On the Ground}

- Information on seasonal trends in quantity and quality of available forage for the goitered gazelle may be useful to wildlife managers in developing management practices to maintain healthy populations and reduce the consumption of toxic plants by protected wildlife.

- Goitered gazelles in Golestan National Park in Iran relied on a variety of grasses, shrubs, and forbs, to meet their nutrituional needs across seasons.

- Increased knowledge of the goitered gazelle's diet is expected to assist wildlife managers in determining carrying capacity and assessing viable habitats for future reintroduction programmes, including overall successful management within the protected areas of Iran.

Keywords: Crude protein, Metabolisable energy, Mineral concentration, Goitered gazelle, nutritional demand, Golestan National Park. 


\section{Figure Captions}

Figure 1. Location of study area and sampling transects in the Golestan National Park of Iran.

Figure 2. Mean seasonal trends in available forages (current annual growth) of three growth forms comprising the gazelle diets in the Golestan National Park of Iran. 
Click here to download high resolution image



Figure 1 
Click here to download high resolution image

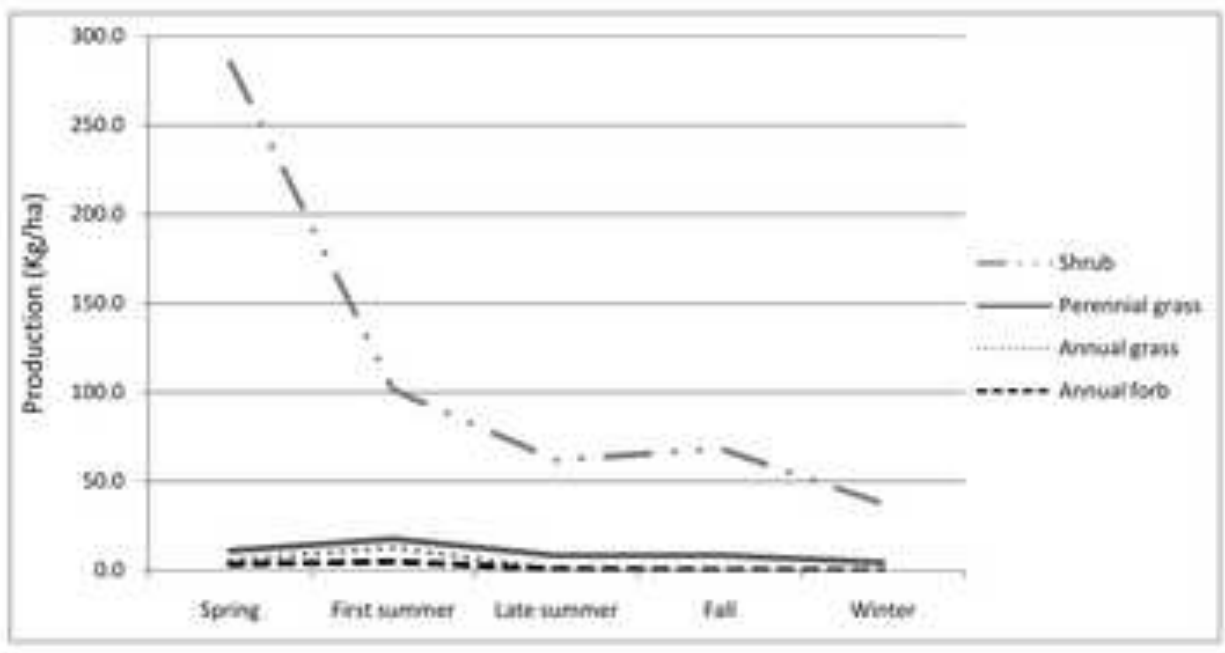

Figure 2 
Table 1. Vegetation types of the gazelle habitat (Mirzabaylou plain) in the Golestan National Park of Iran

\begin{tabular}{lcc}
\hline & Total & $\begin{array}{c}\text { Number of } \\
\text { transects }\end{array}$ \\
& area & (ha) \\
\hline I: Artemisia herba lba/Eremopyrunbonaris/Anabasis aphylla/Aellenia spp & 678.69 & 4 \\
II: Artemisia herba alba /Salsola rigida & 968.63 & 4 \\
III: Artemisia herba alba/ Salsola vermiculata/ Stipa barbata/ Poa bulbosa & 205.00 & 3 \\
IV: Artemisia herba alba/ Erocia ceratoidea /Stipa barbata/ Poa bulbosa & 865.12 & 4 \\
V: Artemisia herba-alba/ Aellenia spp/Annual forbs & 847.70 & 5 \\
\hline Total & $\mathbf{3 5 6 5 . 1 4}$ & $\mathbf{2 0}$ \\
\hline
\end{tabular}


Table 2. Seasonal \% crude protein $(\% \mathrm{DM} \pm \mathrm{Sd})$ fluctuations of the main gazelle diets in the Golestan National Park of Iran

\section{Seasons}

\begin{tabular}{|c|c|c|c|c|}
\hline Species & Mid spring (\%) & End spring (\%) & Midsummer (\%) & First Fall (\%) \\
\hline \multicolumn{5}{|l|}{ Shrubs } \\
\hline Artemisia herba-alba & $15.98 \pm 1.40^{\mathrm{A}}$ & $15.33 \pm 1.52^{\mathrm{AB}}$ & $12.55 \pm 0.74^{\mathrm{B}}$ & $8 \pm 0.57^{C}$ \\
\hline Eurotia ceratoides & $15.96 \pm 0.56^{\mathrm{A}}$ & $15.33 \pm 0.57^{\mathrm{A}}$ & $16.31 \pm 1.70^{\mathrm{A}}$ & $7.87 \pm 0.17^{\mathrm{B}}$ \\
\hline Salsola rigida & $17.80 \pm 0.48^{\mathrm{A}}$ & $17.33 \pm 0.57^{\mathrm{A}}$ & $14.06 \pm 0.60^{\mathrm{B}}$ & $11 \pm 0.01^{\mathrm{C}}$ \\
\hline Salsola vermiculata & $11.89 \pm 1.48^{\mathrm{A}^{*}}$ & $10.43 \pm 0.62^{\mathrm{A}^{*}}$ & $7.48 \pm 0.61^{\mathrm{B}^{*}}$ & $7 \pm 1^{\mathrm{B}}$ \\
\hline Anabasis aphylla & $28.65 \pm 0.13^{\mathrm{A}}$ & $27.66 \pm 0.57^{\mathrm{A}}$ & $22.04 \pm 2.36^{\mathrm{B}}$ & $15.98 \pm 0.53^{\mathrm{C}}$ \\
\hline Aellenia spp & $20.77 \pm 0.74^{\mathrm{A}}$ & $20.25 \pm 1.09^{\mathrm{A}}$ & $14.34 \pm 0.08^{\mathrm{B}}$ & $8.92 \pm 0.35^{\mathrm{C}}$ \\
\hline \multicolumn{5}{|l|}{ Grasses } \\
\hline Stipa barbata & $18.33 \pm 1.27^{\mathrm{A}}$ & $9.49 \pm 1.01^{\mathrm{B}^{*}}$ & $8 \pm 0.22^{\mathrm{B}^{*}}$ & $7.66 \pm 0.57^{\mathrm{B}}$ \\
\hline Poa bulbosa & $17.36 \pm 0.39^{\mathrm{A}}$ & $5.77 \pm 0.61^{\mathrm{B}^{*}}$ & $6.95 \pm 2.23^{\mathrm{B}^{*}}$ & $6.33 \pm 2.51^{\mathrm{B}^{*}}$ \\
\hline Eremopyron bonaris & $11.28 \pm 1.48^{\mathrm{A}^{*}}$ & $10.09 \pm 1.01^{\mathrm{A}^{*}}$ & $9.44 \pm 0.17^{\mathrm{A}^{*}}$ & - \\
\hline \multicolumn{5}{|l|}{ Forbs } \\
\hline Alyssum strigosum & $10.38 \pm 1.25^{\mathrm{A}^{*}}$ & $9.70 \pm 0.61^{\mathrm{A}^{*}}$ & $9.18 \pm 0.87^{\mathrm{A}^{*}}$ & - \\
\hline G* Gazelle Requirements & 14 & 14 & 12 & $7 \%$ \\
\hline
\end{tabular}

${ }^{* *}$ Good requirements were supposed nutritional levels in which there were no limitations in reproduction, survival, growth rate of wild animals ${ }^{4}$.

${ }^{\mathrm{ABC}}$ Means in the same row followed by the same uppercase superscript are not significantly different $(\mathrm{P}>0.05)$ as tested by Tukey-Kramer HSD tests.

*Estimate less than good requirement. 
Table 3. Energy budget of the goitered gazelles (MegaJoules per individual per 24-hour period)

\begin{tabular}{|c|c|c|c|c|c|c|c|}
\hline \multirow{2}{*}{ Species } & \multirow{2}{*}{$\begin{array}{l}\text { Body } \\
\text { mass } \\
(\mathrm{Kg})\end{array}$} & \multicolumn{6}{|c|}{ Energy requirements $\left(\mathrm{MJ}\right.$ ind $\left.^{-1} 24^{-1} \mathrm{~h}\right)$} \\
\hline & & Maintenance & Lactation & Mating & Feeding & Walking & Resting/standing \\
\hline Male gazelle & 24 & 4.77 & - & 5.82 & 7.15 & 11.92 & 5.48 \\
\hline Female gazelle & 20 & 4.16 & 9.65 & 5.12 & 6.25 & 10.4 & 4.47 \\
\hline
\end{tabular}


Table 4. Seasonal metabolisable energy (MegaJoules per kg Dry Matter $\pm S_{d}$ ) fluctuations in the main gazelle diets in the Golestan National Park of Iran

\begin{tabular}{|c|c|c|c|c|}
\hline \multirow[b]{2}{*}{ Species } & \multicolumn{3}{|c|}{ Seasons } & \multirow[b]{2}{*}{ First Fall } \\
\hline & Mid spring & End spring & Mid-summer & \\
\hline \multicolumn{5}{|l|}{ Shrubs } \\
\hline Artemisia herba-alba & $8.93 \pm 0.24^{\mathrm{A}^{*}}$ & $8.60 \pm 0.36^{\mathrm{AB}^{*}}$ & $8.17 \pm 0.19^{\mathrm{B}}$ & $7.52 \pm 0.02^{C}$ \\
\hline Eurotia ceratoides & $8.30 \pm 0.17^{\mathrm{A}^{*}}$ & $8.20 \pm 0.20^{\mathrm{A}^{*}}$ & $8.53 \pm 0.33^{\mathrm{A}}$ & $7.09 \pm 0.05^{\mathrm{B}}$ \\
\hline Salsola rigida & $9.97 \pm 0.03^{\mathrm{A}}$ & $9.73 \pm 0.30^{\mathrm{A}}$ & - & $9.70 \pm 0.21^{\mathrm{A}}$ \\
\hline Salsola vermiculata & $10.74 \pm 0.24^{\mathrm{A}}$ & $8.25 \pm 0.09^{\mathrm{B}^{*}}$ & $7.09 \pm 0.05^{\mathrm{C}}$ & - \\
\hline Anabasis aphylla & $11.87 \pm 0.27^{\mathrm{A}}$ & $11.50 \pm 0.436^{\mathrm{A}}$ & $10.46 \pm 1.64^{\mathrm{A}}$ & $10.10 \pm 1.83^{\mathrm{A}}$ \\
\hline Aellenia spp & $11.66 \pm 0.12^{\mathrm{A}}$ & $10.79 \pm 0.68^{\mathrm{AB}}$ & $9.62 \pm 0.84^{\mathrm{BC}}$ & $8.85 \pm 0.09^{\mathrm{C}}$ \\
\hline \multicolumn{5}{|l|}{ Grasses } \\
\hline Stipa barbata & $8.82 \pm 0.11^{\mathrm{A}^{*}}$ & $7.49 \pm 0.28^{\mathrm{B}^{*}}$ & $7.17 \pm 0.15^{\mathrm{B}}$ & $7.17 \pm 0.15^{\mathrm{B}}$ \\
\hline Poa bulbosa & $9.01 \pm 1.43^{\mathrm{A}^{*}}$ & $7.36 \pm 0.16^{\mathrm{AB}^{*}}$ & $6.68 \pm 0.12^{\mathrm{B}}$ & $6.03 \pm 0.17^{\mathrm{B}}$ \\
\hline Eremopyron bonaris & $8.32 \pm 0.036^{\mathrm{A}^{*}}$ & - & $7.56 \pm 0.15^{\mathrm{B}}$ & - \\
\hline \multicolumn{5}{|l|}{ Forbs } \\
\hline Alyssum strigosum & $7.16 \pm 0.05^{\mathrm{A}^{*}}$ & - & $5.50 \pm 0.27^{\mathrm{B}}$ & - \\
\hline Energy Requirements & 9.65 & 9.65 & 4.46 & 5.5 \\
\hline
\end{tabular}


Table 5. Concentration range of macro minerals (parts per million or $\mathrm{mg} / \mathrm{kg} \mathrm{DM}$ ) in the typical gazelle forage during spring and fall compared with requirements during lactating to rutting periods and maximum tolerable levels. Requirement levels are from Van Soest ${ }^{14}$ and maximum tolerable levels are based on the National Research Council ${ }^{18}$.

\begin{tabular}{|c|c|c|c|c|c|c|c|c|}
\hline \multirow[b]{2}{*}{ Species } & \multicolumn{2}{|c|}{$\mathrm{Na}$} & \multicolumn{2}{|c|}{$\mathrm{Mg}$} & \multicolumn{2}{|c|}{ K } & \multicolumn{2}{|c|}{$\mathrm{Ca}$} \\
\hline & Spring & Fall & spring & fall & Spring & fall & spring & Fall \\
\hline \multicolumn{9}{|l|}{ Shrubs } \\
\hline Artemisia herba-alba & 4761.6 & 549.44 & $1048.9^{*}$ & 1154.42 & $2679.3^{*}$ & 5967.92 & $3583.5^{*}$ & 3665.10 \\
\hline Eurotia ceratoides & 1786.99 & 6266.89 & $1682.45^{*}$ & 3706.89 & $3656.00^{*}$ & 6086.99 & $3911.38^{*}$ & 8581.37 \\
\hline Salsola rigida & 888.68 & 3120.57 & $944.37^{*}$ & 479.39 & $1154.26^{*}$ & $4851.02^{*}$ & 4287.89 & 11523.28 \\
\hline Salsola vermiculata & 493 & - & 49891 & - & $2424.08^{*}$ & - & 8065.43 & - \\
\hline Anabasis aphylla & 2677.16 & 2827.97 & 5351.83 & 5651.31 & $1309.57^{*}$ & $2745.81^{*}$ & $3444.02^{*}$ & 1915.58 \\
\hline Aellenia spp & $344.54^{*}$ & 959.46 & $784.92^{*}$ & 2419.94 & $1929.93^{*}$ & $5322.54^{*}$ & $1252.03^{*}$ & 3921.31 \\
\hline \multicolumn{9}{|l|}{ Grasses } \\
\hline Stipa barbata & $49.58^{*}$ & $48.46^{*}$ & $844.40^{*}$ & $390.46^{*}$ & $5374.46^{*}$ & $4265.04^{*}$ & $3191.36^{*}$ & $851.72^{*}$ \\
\hline Poa bulbosa & $112.01^{*}$ & $226.81^{*}$ & $1621.26^{*}$ & $739.02^{*}$ & $5569.50^{*}$ & 6275.47 & 5022.31 & 1753.02 \\
\hline Eremopyron bonaris & 595.99 & - & $546.81^{*}$ & - & $4600.73^{*}$ & - & $1098.32^{*}$ & - \\
\hline Average & 1301.06 & 1999.43 & 1979.34 & 3363.06 & 3188.65 & 5073.54 & 3761.80 & 4601.62 \\
\hline Requirement levels & \multicolumn{2}{|c|}{500} & 2000 & 1000 & 7000 & 6000 & 4000 & 1600 \\
\hline Maximum tolerable levels & \multicolumn{2}{|c|}{100,000} & \multicolumn{2}{|c|}{4000} & \multicolumn{2}{|c|}{30,000} & \multicolumn{2}{|c|}{20,000} \\
\hline
\end{tabular}

*Estimate less than requirement levels

-Values expressed in bold have exceeded the requirement levels

- Values expressed in circle have exceeded the maximum tolerable levels 
Table 6. Concentration range of micro minerals (parts per million or $\mathrm{mg} / \mathrm{kg}$, DM) in the typical gazelle forage during spring and fall to compared with minimum requirements and maximum tolerable levels. Minimum requirements are from the Agricultural Research Council $^{34}$ and maximum tolerable levels are based on the National Research Council ${ }^{18}$.

\begin{tabular}{|c|c|c|c|c|c|c|c|c|c|c|c|c|c|c|c|c|c|c|c|c|}
\hline \multirow[b]{2}{*}{ Species } & \multicolumn{2}{|c|}{$\mathrm{Fe}$} & \multicolumn{2}{|c|}{$\mathrm{Mn}$} & \multicolumn{2}{|c|}{$\mathrm{Zn}$} & \multicolumn{2}{|c|}{$\mathrm{Cu}$} & \multicolumn{2}{|c|}{$\mathrm{Cr}$} & \multicolumn{2}{|c|}{ Co } & \multicolumn{2}{|c|}{$\mathrm{Ni}$} & \multicolumn{2}{|c|}{ As } & \multicolumn{2}{|c|}{$\mathrm{Cd}$} & \multicolumn{2}{|c|}{$\mathrm{Pb}$} \\
\hline & spring & Fall & Spring & Fall & Spring & Fall & spring & fall & spring & Fall & spring & fall & spring & fall & spring & Fall & spring & fall & spring & fall \\
\hline \multicolumn{21}{|l|}{ Shrubs } \\
\hline Artemisia herba-alba & 156.47 & 408.97 & 33.78 & 34.29 & $7.55^{*}$ & 20.72 & $3.60^{*}$ & 7.24 & 0.30 & 1.27 & $0.10^{*}$ & 0.22 & 0.70 & 1.67 & 0.53 & 1.03 & 0.02 & 0.06 & 0.27 & 0.92 \\
\hline Eurotia ceratoides & 73.87 & 526.57 & 22.96 & 57.48 & $6.12^{*}$ & $5.27^{*}$ & $1.91^{*}$ & $3.45^{*}$ & 0.12 & 1.37 & $0.07^{*}$ & 0.34 & 0.43 & 1.44 & 0.52 & 1.68 & 0.03 & 0.09 & 0.23 & 0.97 \\
\hline Salsola rigida & 45.85 & 311.95 & 14.37 & 74.57 & $3.66^{*}$ & $5.04^{*}$ & $1.11^{*}$ & $2.75^{*}$ & 0.07 & 0.63 & $0.03^{*}$ & $0.16^{*}$ & 0.25 & 1.17 & 0.33 & 1.22 & 0.06 & 0.06 & 0.08 & 0.44 \\
\hline Salsola vermiculata & 75.06 & - & 30.11 & - & $1.32^{*}$ & - & $0.67^{*}$ & - & 0.15 & - & $0.08^{*}$ & - & 0.38 & - & 0.76 & - & 0.02 & - & 0.09 & - \\
\hline Anabasis aphylla & 38.76 & 39.56 & 23.36 & 11.48 & $7.85^{*}$ & $7.40^{*}$ & $2.34^{*}$ & $2.07^{*}$ & 0.09 & 0.10 & $0.03^{*}$ & $0.03^{*}$ & 0.61 & 0.50 & 0.39 & 0.38 & 0.05 & 0.05 & 0.06 & 0.05 \\
\hline Aellenia spp & 42.39 & 137.13 & 16.95 & 33.63 & $2.13^{*}$ & $3.04^{*}$ & $0.76^{*}$ & $2.30^{*}$ & 0.11 & 0.93 & $0.03^{*}$ & $0.09^{*}$ & 0.11 & 0.33 & 0.22 & 0.69 & 0.04 & 0.07 & 0.04 & 0.19 \\
\hline \multicolumn{21}{|l|}{ Grasses } \\
\hline Stipa barbata & 107.48 & 48.52 & 41.50 & 18.28 & $9.38^{*}$ & $7.53^{*}$ & $3.73^{*}$ & $2.44^{*}$ & 0.31 & 0.18 & $0.06^{*}$ & $0.03^{*}$ & 0.54 & 0.39 & 0.65 & 0.40 & 0.01 & 0.02 & 0.17 & 0.28 \\
\hline Poa bulbosa & 271.56 & 133.72 & 85.48 & 31.26 & $9.21^{*}$ & $7.75^{*}$ & $3.81^{*}$ & $2.42^{*}$ & 0.83 & 0.63 & $0.16^{*}$ & $0.10^{*}$ & 0.94 & 0.67 & 0.88 & 0.76 & 0.01 & 0.02 & 0.26 & 0.27 \\
\hline Eremopyron bonaris & 82.40 & - & 22.61 & - & $7.13^{*}$ & - & $2.03^{*}$ & - & 0.29 & & $0.05^{*}$ & - & 0.21 & & 0.44 & & 0.01 & & 0.12 & \\
\hline Average & 99.32 & 229.48 & 32.35 & 37.28 & 6.04 & 8.10 & 2.22 & 3.23 & 0.25 & 0.73 & 0.07 & 0.13 & 0.46 & 0.88 & 0.52 & 0.88 & 0.03 & 0.05 & 0.15 & 0.44 \\
\hline Minimum requirements & \multicolumn{2}{|c|}{30} & \multicolumn{2}{|c|}{10} & \multicolumn{2}{|c|}{20} & \multicolumn{2}{|c|}{5} & \multicolumn{2}{|c|}{ NA } & \multicolumn{2}{|c|}{0.20} & \multicolumn{2}{|c|}{ NA } & \multicolumn{2}{|c|}{$\mathrm{NA}$} & \multicolumn{2}{|c|}{$\mathrm{NA}$} & \multicolumn{2}{|c|}{ NA } \\
\hline Maximum tolerable levels & \multicolumn{2}{|c|}{500} & \multicolumn{2}{|c|}{200} & \multicolumn{2}{|c|}{300} & \multicolumn{2}{|c|}{25} & \multicolumn{2}{|c|}{ NA } & \multicolumn{2}{|c|}{10} & \multicolumn{2}{|c|}{ NA } & \multicolumn{2}{|c|}{ NA } & & & & \\
\hline
\end{tabular}

"Estimate less than minimum requirements

- Values expressed in bold have exceeded the minimum requirements

- Values expressed in circle have exceeded the maximum tolerable levels

- NA, no available data in the references 